\title{
Preference of Twelve Perennial Grass Pasture Mixtures Under Horse Grazing
}

\author{
Krishona L. Martinson ${ }^{1}$ and Craig C. Sheaffer ${ }^{2}$ \\ ${ }^{1}$ Associate Professor, Department of Animal Science, University of Minnesota \\ ${ }^{2}$ Professor, Department of Agronomy and Plant Genetics, University of Minnesota
}

Perennial grasses are the foundation of horse pastures in the North Central U.S. Horses are selective grazers, and recent research has shown that horses have a strong preference for Kentucky bluegrass, timothy, and meadow fescue. However, horse pastures are rarely planted to a single species. Planting mixtures is common; however, mixtures are rarely evaluated under horse grazing. The objective of this research was to evaluate horse preference of perennial grass pasture mixtures. Research was conducted in 2011 and 2012 in MN. Four adult horses grazed eight commercially marketed and four experimental perennial grass pasture mixtures. Mixtures contained four to six of the follow species; orchardgrass, reed canarygrass, meadow fescue, Kentucky bluegrass, perennial ryegrass, smooth bromegrass, meadow bromegrass, timothy or festulolium. The experimental design was a randomized complete block with five replicates. Individual plots were $1.8 \times 6.0 \mathrm{~m}$, and horses were given access to the entire plot area $(37 \times 22 \mathrm{~m})$. Grazing was initiated when most grasses averaged $20 \mathrm{~cm}$. Horses were allowed to graze the area for 5 days, averaging 4 hours of grazing each day. This grazing length was selected to achieve a minimum average residual height of $9 \mathrm{~cm}$ to avoid overgrazing. After grazing, manure was removed, plots were mowed to $9 \mathrm{~cm}$ and allowed to regrow. Horses were given ad libitum access to water, housed in a dry lot, and fed grass-alfalfa hay when not grazing. Immediately after grazing, plots were visually assessed for percent of available forage removal on a scale of 0 (no grazing activity) to 100 (100\% of existing vegetation grazed to a 9 $\mathrm{cm}$ height) to determine horse preference. Data were analyzed as climatological seasons including spring (grazing initiated May 12, 2011 and April 27, 2012), summer (July 13, 2011 and June 5, 2012), and fall (September 9, 2011 and August 28, 2012) using the ANOVA procedure of SAS, with statistical significance set at $P \leq 0.05$. There was no season $\times$ year $\times$ mixture interaction $(P=0.0511)$; data were combined over seasons and years. Horses showed distinct preferences among the mixtures $(P<0.001)$. Mixtures that included meadow fescue, Kentucky bluegrass, perennial ryegrass, and timothy were the most preferred with $\geq 86 \%$ of the forage removed by horse grazing. Deviating from this combination reduced horse preference. Simply adding orchardgrass to the most prefered mixtures reduced $(P<0.001)$ horse preference to $71 \%$. Removing meadow fescue or Kentucky bluegrass and timothy from the most preferred mixtures and adding meadow bromegrass and/or orchardgrass resulted in the least preferred mixtures with a preference of $55 \%(P \leq 0.001)$. This agrees with previous reseach that showed horses did not prefer orchardgrass or meadow bromegrass. To maximize forage use and promote uniform grazing, mixtures containing meadow fescue, Kentucky bluegrass, perennial ryegrass, and timothy should be planted in horse pastures in the North Central U.S. 